\title{
Thrown Away Like Rubbish - Disposal of the Dead in Ancient Greece
}

\author{
Astrid Lindenlauf \\ Institute of Archaeology, UCL.
}

\begin{abstract}
In this article, the literary and archaeological evidence for burial practices that can be associated with the English expression 'to be disposed of like rubbish' are discussed. These disposal methods (átaphon rhiptesthai) include the exposure of corpses to carrion animals, to the elements, as well as the disposal of corpses into the sea, pits or natural fissures without burial rites. They also include cases in which graves were dug up in order to throw their contents out. Here, the Greek expressions for the English phrase 'to be thrown away like rubbish' are explored, as well as its relation to Morris' (1987) influential concept of the 'non-formal burial'. The analysis of the symbolism of various disposal methods has been based on both literary and archaeological sources. Also addressed are issues such as the intersection of the exclusion from full and proper burial procedures with social status and social groups. Lastly, the dangers for the living and the dead associated with casually disposed of human remains are briefly tackled, including the transformation of the souls of the deceased into spirits and their loss of human-ness.
\end{abstract}

\section{Introduction}

Whilst working on my doctoral thesis on ancient Greek waste management, news of a human body that was discovered by police after it had been thrown away like a piece of rubbish, and the well-known photo of a Bosnian corpse surrounded by garbage, which was taken by Fullone (Vergine 1997, 195, fig. 214), drew my attention to the fact that not only objects and materials were thrown away like, or together with, rubbish, but also the physical remains of humans. In our society, the case is clear. Proper burial of corpses is the norm and the casual disposal of the physical remains of humans is socially unacceptable. Since I was exploring the practices of disposal and recycling in ancient Greece, I was not so much interested in the casual disposal of the physical remains of modern people, but rather in those of ancient Greeks. In the course of my research, I discovered that this topic has already gained some interest among historians and philologists such as Parker (1996, 45, 70, 170, $190,195)$ and D'Onofrio $(1993,146)$ as well as archaeologists such as Themelis (1982), Pritchett (1985b, 235-41), Morris (1987) and Bergemann (1999, 46).

These authors have briefly tackled aspects such as the disposal of corpses and (already buried) human bones as well as accumulations of human bones and the lack of burials of the lower social class in the archaeological record of geometric and archaic Attica. However, a synthetic study based on the critical discussion of both the relevant literary sources, which tend to shed light on the public and male-dominated domain of archaic and classical Athens, and archaeological sources, which tend to illuminate a much longer time-span and a much broader topographical area, has not been presented. This gap should be closed here. More specifically, I aim to explore the Greek expressions for, and the social implications of, the English phrase "to be thrown away like rubbish". In addition, I shall give an overview of disposal techniques and their application. I shall also analyse which social groups and individuals were denied burial rites with a view to exploring the frequency as well as the social 
and cultural significance of this practice across time and space. The different threads shall be brought together in the conclusions.

\section{Ancient Greek Concepts}

The ancient Greeks, it seems, did not use a metaphor associated with rubbish to express the disposal of corpses in a casual way. This is not too surprising, as the concept of rubbish as a generic term for everything which is unwanted is quite a recent development and is characteristic of the throw-away societies of Western Europe and the United States. The most frequently used phrases for the casual disposal of human remains in ancient Greek sources contained constructions with verbs meaning 'throwing away', including verba composita of bállein and phrases containing the verb rhiptein, such as átaphon rhiptesthai (i.e. to be thrown away without a tomb, grave, a funeral-feast or rites of burial according to Lidell et al. 1951).

In this context, a passage written by Diogenes Laertios $(6.79$, cf. $S V G 1,253)$ is relevant, in which he noted Diogenes' instructions regarding the treatment of his corpse. The Cynic philosopher wished that his remains should be thrown out unburied or into the Ilissos. The explanations given for these unusual orders are that the Cynic aimed at either providing fodder for 'every wild beast' or being 'useful to his brothers'. These statements are a powerful demonstration of the extension into the next life of the value system on which his philosophy was based. Of crucial importance for this context is Diogenes conceptualisation of animals in his understanding of the world: he denied the superiority of humans over animals. Here, he takes his approach to an extreme point, but the idea that animals are not inferior to humans can also be found in other passages, for instance, when he stated that people could learn from the behaviour of mice (Diogens Laertios 6.22).

Diogenes was not a mainstream philosopher and his ideals were, thus, not shared by the majority of the Greek population. Their label Cynic, meaning dog-like, identified their body of canonical rules as shameless. That the Greek world view was based on the binary opposition of humans and animals can be deduced from the rhetoric of forensic speeches. In particular, Demosthenes (25.1.58; 56.1.70, cf. Dinarchos 1.50) frequently called traitors and law-breakers who used to be disposed of without burial rites, miaroi (shameless and disgusting creatures) and animals (thería; ágrioi). In addition, human flesh was considered an inappropriate and abominable source of food by most of his fellow citizens (e.g. Herodotos 3.38; Pausanias 10.4.8). It may, therefore, be concluded that the adult population was afraid of losing its human-ness and of becoming as low as animals. 'To be disposed of without burial rites' (átaphon rhiptesthai) seems to have been synonymous with to 'be disposed of like an animal' and 'to be disposed of like a Cynic', that is to say 'to be shamelessly disposed of'. Thus, the Greek equivalent to the English phrase 'to be disposed of like rubbish' may be formulated as 'to be disposed of like an animal'.

It is noteworthy that átaphon rhiptesthai (the deposition of corpses without a burial or without a token act of burial rites respectively) is not synonymous with Morris' influential category of the 'non-formal burial', as it is an ambiguous term (cf. Morris 1987). 'Unformal burials' can be understood in terms of depositions of low archaeological visibility as well as topographically as depositions containing human remains 
outside of "formal, bounded localities reserved exclusively for the disposal of the dead" (Morris 1987, 63, 94; Morris 2000, 99). The former definition includes human remains without a táphos. However, the latter definition does not focus on the way in which the deposition was carried out, but rather on its location. Thus, Morris would not call a deposition consisting of human bones found without grave goods and a proper tomb in a cemetery a casual deposition. This weakness appears to have already been detected by Shepherd, who used the term "unprotected deposition" (Shepherd 1995, 61) for his analysis of a Syracusan cemetery.

\section{Disposal Methods, their Implications and Applications}

The disposal of human remains without a proper burial (átaphon rhiptein) has many faces. The disposal technique considered in this section include the throwing of corpses into pits, natural fissures and bodies of water within and beyond the borders of the community or the city-state (pólis), the exposure of corpses to carrion animals and to the elements. I have excluded human bones that have been found within Geometric houses (Morris 2000, 287; Roncoroni in press, 85 with n. 41), as they may indicate that humans were not treated in any special way or that they were still considered part of the living community (e.g. Morris 1987, 181-2. Cf. Antanaityte 1998; Meiklejohn et al. 1998). Here, I have also interpreted the deposition of human remains on rubbish heaps and in broken and provisional vessels as waste disposal. Lastly, I have examined cases in which the physical remains of the dead were exhumed with a view to casting them out.

It is perhaps noteworthy that the majority of the examples discussed in this section derived from literary sources, owing to the low archaeological visibility of the casual treatment of the dead (cf. Morris 1987, 63, 94; Morris 2000, 99). Thus, it can be expected that the inhuman treatment of the dead is presented as a practice applied to extraordinary people of the 'public' realm. Whether or not the picture drawn from the sources considered in this section is representative, I have discussed in the following section.

Pre-Roman Greece had no institutional program of spectacles, where criminals were sent into the arena to die and to be finally disposed of carelessly (Kyle 1993; 1998, esp. 155-83, 243-8). Instead, ancient Greeks punished their wrong-doers by dumping them into pits or drowning them in water to communicate the worthlessness of these individuals. In Athens and Sparta (Xenophon Hell. 1.7.20), the pólis authorities monopolised the power to punish their foes beyond death by legally sanctioning and carrying out the denial of burial of traitors and heinous criminals. At both póleis (city-states), a standard execution and punishment consisted of throwing (embállesthai) evil-doers into pits or ravines (e.g. Zenobios 6.17). In classical Athens, the most common punishment for anyone who wronged the people of Athens and was judged guilty of crimes against society, was being put to death by being cast into the Deadman's Pit (e.g. Aristophanes Eq. 1362. Pl. 431; Plato Gorg. 516D; Xenophon Hell. 1.7.20). Alternatively, the criminal's dead body, carried from prison, was cast into this pit (eis tò bárathon embállesthai), which was probably located outside the city, below a precipice of the rock of the Pnyx, in the corner between Town Hall and Long Wall (Rogers 1938, 254b; cf. Mahaffy 1883, 266 with n. 1; Garland 1985, 95). This punishment became so common a feature in Athens that the word bárathon meaning 'the place of execution and disposal', came to mean 
'human, who deserves to be cast into the bárathon' or 'criminal' (e.g. Lucianus Pseudol. 17. cf. Aristophanes Pl. 431). The negative connotation of bárathon also becomes evident in the metaphorical use of this word in the sense of ruin.

An execution and disposal place similar to the Athenian bárathon was the Spartian Kaíadas (e.g. Thukydides 1.134.4; 4.80.4; Strabo 5.3.6; 8.5.7; Pausanias 4.18.4-7). They were similar in their function, as they both served to punish not only local men but also enemies from without for what were considered the greatest crimes. They were also similar with respect to their location outside of the boundaries of the pólis and to their physical features, as they were both structures below the surface of the earth. The only significant difference was that the bárathon was a hand-made pit, whereas the Keadas was a natural feature. Local oral tradition located the Keadas either near the village Parori in the district of Mistra or associated it with an abyss at Mt. Tayjetos close to the village Trypi (Papachatzi 1979, 71-2 n. 3; Themelis 1982, 183; Pritchett 1985a, 58-60). As a massive amount of human skeletons, mostly of adults was found spread all over the cave of Trypia, Themelis (1982) and Pritchett (1985a) suggested that this was the ancient Keadas. This interpretation is possible, but it remains to be seen as to whether this execution place was indeed used during the historical period. More specifically, it remains to be seen how the potsherds, which Themelis mentioned (1982), are to be dated.

Another punishment for depriving the dead of honour consisted of prohibiting burial within the borders of the community or being cast into the sea and other bodies of water (cf. Cantarella 1991, 91-105; Parker 1996, 43-7). These methods held a different significance, as they were mainly applied to specific kinds of wrong-doers, namely to temple-robbers, traitors, pirates and suicides. As the best historical evidence for the treatment of convicted temple-robbers comes from Attica, I will base my discussion on it. Temple-robbers and their like were denied the individual's right to burial by throwing their corpses into the sea (katapontizein; katapontóein; e.g. Diodoros 16.35.6; Aeschines Emb. 142; Isokrates 5.115; Demosthenes 25.166) or down a precipice (katakremnizein; e.g. Demosthenes Fleg. 327). Another punitive measure taken against the corpses - and thus against the individuals - was throwing them (ekbállein) beyond the boundaries of the city-state or the political and military Leagues they wronged; This meant in most cases a removal of the corpse beyond the borders of Attica (e.g. Xenophon Hell. 1.7.22; Thukydides 1.126.11-2; Plato Lg. 873B; Lykophron Leocr. 113-4; Hyperides pro Lyc. 20; Plutarchos Phoc. 37.2-3; cf. Graf 1978, 69 n. 54), but occasionally also beyond the boundaries of the Second Athenian League (e.g. SIG3 147.61).

Whenever a person died outside of the boundaries of the community, nonaccordance of the honour of burial and close to the community did not involve the formal disposal of the corpse, but abandonment. The corpse of the Spartan Archidamos III, for example, who died during a war in Tarentum was not recovered from the battlefield and "was not accorded the honour of burial" (Athenaios 536D). In contrast to disposal in water, which affords quick and effective removal, corpses cast beyond the boundaries of a community could be buried discreetly by the relatives, as it happened in the cases of Themistokles (Thukydides 1.138.6, cf. Plutarchos Th. 22.4) and Phokion (Plutachos Phoc. 38.1). If this was not done, they were consumed 
by scavengers, like those flung into the sea (Henderson 1975, 193, no. 417; Parker 1996, 360 with n. 17). The surviving evidence also suggests that the bodies of suicides were disposed of outside of the boundaries of the social community. According to the law of Demonassa, for instance, suicides had to be thrown unburied over the borders in Kypros (Demosthenes 8.64.3, cf. Aeschines ag. Ctes. 244; Plutarchos Them. 22.2).

Plato, in his Leges (9.873D, 874B; cf. Bremmer 1983, 67), laid down that suicides should be formally punished 'for lack of manliness' by being buried, but in a solitary and unmarked grave on the boundaries between the twelve districts, that is in the darkness of anonymity on a piece of land falling outside the ordered, social world. Regulations in Thebes are less explicit, but the denial of receiving any honour may point to the same direction. Suicides also flung themselves into the sea, in particular in mythical times. Evenos, for example, threw himself into the river, which was called Evenos after him (Pseudo-Apollodoros Bib. 1.7.8) as Aegeus, the father of Theseus, threw himself into the sea, which was called after him Aigaion pélagos or simply tò Aigaion (cf. Herter 1973, 1144-6). Alternatively, suicide could be committed by flinging oneself into a precipice (e.g. Pausanias 10.2.4). These methods of extinguishing one's life seem to have been restricted to 'masculine' men; mythical female figures and effeminate men preferred to hang themselves with a rope (Loraux 1987).

The above discussed disposal modes differ in one important aspect. Whereas disposal in the sea was an ultimate disposal practice, disposal beyond the boundaries might have been followed by the reburial of the corpse or the bones. Both disposal modes have also two crucial aspects in common: They both exclude the physical remains of disgraced people from settlements and remove them from sight. Thus, they recall the punishments of ostracism and prohibitions for entering sanctuaries and agorai, even though the expulsion from the community was in these cases imposed on living members (e.g. Plato Gorg. 516D). The disposal of items and people into the sea involved the aspect of 'riddance', as the sea was regarded as a place of no return (e.g. POxy. 661.45-50 col. 2, cf. Kerkhecker 1999, 190-1). Thus, it may be concluded that the disposal methods under discussion aimed, at least partly, also at denying the physical existence of these shameful persons and at wiping out the social memory of them. In any case, the treatment of the bodies of temple-robbers and suicides casts light on the understanding of temple-robbing and suicide as particularly abominable acts against the state, the community.

A further mode of symbolic rejection and humiliation of malefactors beyond death consisted of exposing the dead corpse to carrion animals or the elements within the boundaries of a community. The best known example of this punishment is Kreon's order to leave Polyneikes' body on the plain, that is within the boundaries of the pólis (Sophokles Ant.). An historic case is documented by Plutarchos. He stated that according to one version of the story, Demosthenes and Nikias were put to death by orders of the Syrakusans. The enemies were cast out of the prison door and laid there in plain sight of all that craved the spectacle (Plutarchos Nic. 28.5). Another case of this disposal method may have occurred when the corpse of Olympia was cast out without burial by order of Kasander (Diodoros 17.118.2). If so, this ultimate 
disposal mode was imposed not only on political enemies, but also against a hated dynast. Exposure to carrion animals can be considered as similar to throwing corpses into the sea and beyond the boundaries in that the human body was scavenged and, thus, de facto recycled by animals, if no burial was arranged by the relatives of malefactors. It differs, however, significantly in that the punitive, public violence was acted against malefactors within the boundaries of the community and was, thus, permanently on display.

Exposure was a disposal technique not only employed with adults, but also with unwanted new-born children (cf. Golden 1981, 330-1). Human and divine babies were abandoned for a number of reasons, including disability, illegitimacy, sex, fear of the father that his child may gain power over him, and the economic situation of the parents (Weiss 1921, esp. 464-5; Golden 1981; Dreimann-Merten 1986, 274-81; French 1988, 1356). They were primarily exposed (ekbállein; ektithesthai; apotithesthai) in barren landscape or on dung-hills (kopriai), but also, as in Sparta, cast into chasms. Expulsion from the social community and exposure to the elements or casting into fissures inevitably lead to the death of the new born child. Thus, it may be said that the physical death was preceded by a social death (cf. Hubert 1999). In contrast to the former disposal method, exposure on dung-hills was not necessarily motivated by infanticide and, therefore, did not involve invisibility (cf. Homeros Il. 1.590; 18.3957 (krýbein)).

This disposal method allowed for the baby to be taken by someone in need of a child. In fact, the deposition of the unwanted child on the dung-hill appears to be rooted in the parental wish that the child as the kópros on which it was laid down would go through the stages of "matter out of place" in Douglas" (1995: 41, 126) sense of the term to 'be beneficial to an oikos'. It has been suggested that children taken from dung-hills were given names such as Kopreús and Kopría, but Kajanto (1962, esp. 49, 52-3; cf. Perdrizet 1921, esp. 90) argued persuasively that these names did not denote the origin of the persons apo koprias (from the dung-heaps). The implications of both disposal methods allow conclusions to be drawn about the type of children exposed. Whereas new born babies exposed on dung-hills were most likely healthy and did not have any stain when disconnected from the family, those exposed to the elements were regarded as endangering the stability of the community or living exclusively at the cost of the community due to weakness or disability.

Lastly, human remains found associated with rubbish can be interpreted as an effortless deposition. More specifically, human bones found in broken pottery or already used storage containers indicate casual depositions (cf. Morris 1996: 18), if the recycled pottery had been considered waste. In contrast to the previously discussed disposal technique, this method is less extreme as it shows a minimal effort towards the provision of a burial. Many physical remains of children have been found in nonspecialised burial vessels such as ámphorai (e.g. Kunze-Götte et al. 1999, 1, 31 no. 76, pl. 10.2), píthoi (e.g. Kunze-Götte et al. 1999, 106 no. 414), hýdriai (e.g. KunzeGötte et al. 1999, 15 no. 21A, pl. 10.9), bee-hives (e.g. Lüdorf 1998-9, 41, 53, 78 no. 4, 85 no. B8, fig. 18, pl. 1.14), cooking-pots (e.g. Kunze-Götte et al. 1999, 115 no. 453 , pl. 73.2) and sections of a drain (e.g. Kunze-Götte et al. 1999, 1, 30-1 no. 75, pl. 18.3.6-7) as well as in deliberately broken vessels (e.g. Diehl 1974, 146). It is not 
clear whether all of them result from careless disposal however, as it is unclear whether all individuals considered the vases which they appropriated as provisional burial containers as unwanted and useless pottery - that is to say rubbish - before their conversion. The fact that ámphorai in particular were not considered disposable and were filled with different substances, including wine, honey and meat, suggest that formerly used storage and transport vessels were not considered as useless by everyone (e.g. Lang 1956; Koehler 1986; Lawall 2000, esp. 3, 18). Thus, the finds of bones in fragmented vessels are certainly the most convincing examples of casual disposal of the dead.

All modes of disposal discussed in this section were used for confirming and constructing social hierarchy. The symbolism of these disposal methods, often accompanied with that of corpse abuse, was particularly effectively played with, whenever ancient Greeks wanted to make a statement about the esteem in which captive and military enemies were held. Such a case is documented by Herodotos (7.133), who said that Darios sent diplomats to demand earth from Sparta and Athens and that the demanders were cast into the Deadman's Pit in Athens and into a well in Sparta and bidden to carry hence earth and water to the king. Within the Greek frame of reference, these measures expressed unmistakably that the Persian diplomats were not better than a bárathon. This strategy was also employed by the Syracusans who meant to publicly insult Philistros (efybrizein) beyond death. They achieved this goal by dragging the corpse of Philistros through the whole city and throwing him into the stone quarry, after a period of corpse abuse (Plutarchos Dion. 35.5-7, cf. Diodoros 16.16.4).

The second phenomenon I shall discuss in more detail is the exhumation of the 'indestructible' remains of those long dead with the view to dispose them carelessly (ekbállein) and to deny any further burial. These actions were directed against individuals or members of a family, but also against a larger number of graves. Digging up and casting out dead members of a family was reported, for instance, in connection with the Athenian Alkmeonidai and the Kypselid family at Corinth. In the case of the Alkmeonidai, a curse for their religious crime legitimised exiling the living member, then, digging up and casting out the bones of their dead (e.g. Thukydides 1.126.12 (ekbállein); Plutarchos Sol. 12). The exhumation of the bones of the ancestors of Kypselid tyrants was but one action that took place, when the last of the Kypselid tyrants at Corinth was killed (e.g. Nikolaus Damaskenos fr. 60 (Jacoby 1923), cf. Kyle 1998, 150 n. 58). The belated denial of further burial went hand in hand with the extinction of this family, the confiscation of the property and the denial of burial for the last Kypselid tyrant. Thus, at Athens and Corinth, the exhumation of the physical remains displayed and made public the detestable nature of the dead and made them equal to all those traitors and heinous criminals who were denied burial.

Excavated cemeteries document that in the course of the preparation of a new burial older tombs were destroyed and their contents thrown away like rubbish. For example, in the necropolis $\mathrm{S}$ on the Greek island of Samothrake a considerable number of human bones (grave-markers as well as grave goods), were found in fills (Dusenbery 1998, 8). Phenomenologically, the treatment of the bones in the Samothrakan cemetery is the same as those of the well known Kypselid family. They differ, however, 
significantly in terms of their symbolism, as the casual disposal of the dead from Samothrake was most likely not an intentional action directed against a specific individual or a family with a view to demolishing the high esteem in which the individual was held in his life.

To conclude, the above discussed literary and archaeological sources create the impression that most adults were extremely sensitive to the fate of their corpse. The exclusion from burial was regarded as socially unacceptable. It was typically practiced by all kinds of non-humans such as the Cynic philosophers - whose very label Cynic, meaning dog-like, identified them as inhuman and shameless -, and Sirens (Homer Od. 12.44-6). Denial of a táphos (grave, tomb, funeral rites) was considered a horrendous crime and an expression of terror, if committed by oligarchs.

Being thrown away like rubbish, was considered by the adult population an undesirable fate. However, the casual disposal of corpses was socially tolerated in extreme situations such as war (cf. Pritchett 1985b, 235-41, but 125-39). In addition, the ultimate insult and humiliation of denial of burial was socially acceptable, if legalised by pólis authorities in order to protect the security and rights of citizens (e.g. Diodoros 16.25.2; Aeschines Emb. 142; Demosthenes Fleg. 327; Xenophon Hell. 1.7.22; Thukydides 1.138.6, probably also Lysias Paristoph. 7) or to punish enemies (Plutarchos Nikolaus Nic. 28.5), or if imposed on wrongdoers by public fury, as in the case of Philistros. Punitive disposal methods aimed at hiding a corpse away forever or displaying it unburied as well as allowing it to be scavenged by carrion animals made visible the understanding of violators of fundamental social principles as animal like and shameless. Interestingly, unburied corpses of public enemies were exposed in settlements even at times when the deposition of corpses in formal burial grounds outside of habitation quarters were the norm. This may support the point of view that public enemies were regarded as non-human, as the corpses of ordinary people were considered polluting (Parker 1996, 42, 46).

\section{Casual Disposal and Social Groups}

Apart from the archaeological and literary sources discussed in connection with disposal techniques, the social importance of burial for adults can also be deduced from one of the Bouzygean curses threatening everybody neglecting the human obligation of burial (cf. Parker 1996, 44 with n. 44) and excavated mass-burials with minimal burial rites even in extreme situations such as war (Pritchett 1985b, 26, 235-41) and the plague (Axarlis 1998; Baziotopoulou-Valavani and Tsirigoti-Drakotou 2000, 265-74) and after the purification of a sacred site (Romaios 1929; Morris 2000, 245 with n. 41).

Analysing burials in Athens and Attica, from the subgeometric period to the end of the archaic period, Morris $(1987 ; 1989 ; 1992 / 3$; 1995; 1996; 1998; 2000, 99) concluded that the majority of adults and children were excluded from burial in Athens and Attica, from c. 1050 to $750 \mathrm{BCE}$ and from 700 to $525 \mathrm{BCE}$. More specifically, he stated that a proper burial was reserved for the dead members of the élite (agathoi), whilst the dead of the lower orders (kakoi) were casually disposed of outside of formal burial grounds. From 750 to 700 and after 525 BCE, the total number 
of tombs in formal burial grounds increased, indicating that the burial group widened.

At first sight, Morris' far reaching conclusions seem to contradict my results. However, the literary and archaeological sources discussed so far illuminate only the mythological time evoked in Classical tragedies and the norms and customs of the Homeric, the late archaic and the Classical Greek society. Thus, the picture drawn by Morris from negative evidence (i.e. the absence of burials) enriches and modifies that drawn from positive evidence (i.e. literary and archaeological evidence documenting casual disposal).

Morris' methodology, his chain of argument and his interpretation of the archaeological evidence have been criticised (cf. Morris 1998, 27-30; Köberle and Rohweder 1991-2; Bergemann 1999), so that his conclusions cannot be incorporated into my study without a critical discussion of his theoretical and methodological framework. On a methodological level, some authors have pointed out that the figures on which Morris based his statistical and interpretative approach are dubious. More specifically, it has been rightly noted that Morris did not take into account in his estimations of the size of cemeteries and plots (areas in cemeteries occupied by a single social burial group) and his calculations of the number of excavated and missing tombs the following factors: not all cemeteries have been excavated or published (e.g. Antonaccio 1989, 297; Köberle and Rohweder 1991-2, 12-3); not all burials of a cemetery have been found (e.g. Köberle and Rohweder 1991-2, 11); the date of tombs is often ambiguous (e.g. Köberle and Rohweder 1991-2, 11; Bergemann 1999, 45).

In addition, some authors (e.g. Köberle and Rohweder 1991-2, 9-10; Bergemann $1999,45)$ stressed that the identification of plots, which are key elements in the determination of the changing size of burial groups, are arbitrary. Furthermore, Bergemann $(1999,41)$ argued that Morris' calculation of the number of burials which are to be expected in a cemetery (from which he estimated the total number of individuals whose remains were disposed of without a token act of burial) is dubious as this mathematical operation is based on data from prehistoric necropoleis. However, these methodological inaccuracies do not seriously affect Morris' data, Bergemann (1999, 44. cf. Köberle and Rohweder 1991-2, 13) also concluded, as the analysis of mortuary variability (variability of grave goods) across time seems to support Morris' point of view.

On a theoretical level, Morris explained the changing number of burials neither with Snodgrass $(1980,22-4)$ in terms of demographic changes nor with Camp (1979) in terms of a natural disaster. Instead, he understood and interpreted the increasing number of burials in Athens and Attica around 750 and 525 BCE and their decreasing amount around $700 \mathrm{BCE}$ with the development of the Greek city-state (pólis). More specifically, he argued that only full members of the community were buried and that the group of people eligible for a burial widened with "the triumph of a middling ideology" after the collapse of Dark Age forms of hierarchy (Morris 2000, 287). Morris' interpretative approach is more attractive than Camp's, as the occurrence of a drought has been called into question by some authors (e.g. Lang 1996, 
125-7). In addition, the rise of the Greek city-state around $750 \mathrm{BCE}$ is also accepted by historians (e.g. Stein-Hölkeskamp 1989, esp. 206). However, archaic child cemeteries at Attic sites (cf. Kurtz \& Boardman 1971, 72) seem to support rather the model of Snodgrass than that of Morris, as it is difficult to explain why children qualified for a burial in times when the majority of the adult population was thrown away like rubbish.

To conclude, it is possible that the casual disposal of the deceased was the norm for the majority of the Attic adult population, from 1025 to the rise of the city-state around $750 \mathrm{BCE}$ and after the reinstating of the aristocratic regime around 700 to socio-political changes brought about by Kleisthenes at the end of the sixth century. Apart from the lower classes (kakoi), children have traditionally been associated with careless and effortless disposal, from the Dark Age to the Classical period (e.g. Bremmer 1983, 96; Sourvinou-Inwood 1995, 430-1). Sourvinou-Inwood (1995, 429-33) stated that, from the eighth century BCE, child burials involved more effort and energy spent and that the differentiation between the deposition of children and adults diminished, both in main cemeteries and in separate necropoli. The careless disposal of sub-adults has been explained in terms of the understanding of sub-adults as insignificant, marginal beings and non-personae (Parker 1996, 41). However, research at cemeteries such as in Klazomenai suggests that the economic situation of the family played a crucial role in the ways in which the physical remains of humans were disposed of, as here carefully placed child corpses with precious grave goods were found along with those placed in broken ámphorai (pers. comm. B. Hürmüzlü). Whether other marginal social groups such as slaves were disposed of without a token act of burial on a regular basis is not known (cf. Pomeroy 1997, 116).

\section{Social Implications}

The disposal of the dead like rubbish has mainly been associated with people who were not full members of Greek society, including the kakoi in Attica (from 1025750 and 700-525 BCE), children (particularly in Geometric Greece), and perhaps also slaves, as well as individuals who had acted beyond the limits of human society and custom, including temple-robbers, traitors, tyrants, captive enemies, foreign soldiers, rebels and suicides. In most cases, the refusal of burial was understood in terms of a post-mortem sanction destroying the identity of humans and altering permanently the esteem in which a person was held (e.g. Homeros Il. 4.174; 21.320; Sophokles Ant; Euripides Suppl. Women; Thukydides 2.52.4; Diogenes Laertios 6.79). The individual whose physical remains were casually thrown away did not only face the loss of his/her human-ness. Casual disposal could also preclude the soul from becoming part of the community of the dead and thus force it to become a wandering spirit or ghost (cf. Felton 1999, 9-12; Hope 2000, 106).

\section{Conclusions}

Given that Morris' analysis and interpretation of the archaeological evidence is correct, the kakoí (lower orders of Greek society) received little recognition in life and death, as they left little to no archaeologically detectable traces from 1025 to 750 $\mathrm{BCE}$ and from 700 to $525 \mathrm{BCE}$. Casual disposal was also the norm for children, in particular before the eighth century BCE. Following Morris, more people participated in community affairs and qualified for a burial, from the late sixth century. 
When burial became the norm, the casual treatment of corpses of ordinary citizens was regarded by most Greek citizens - except for minority groups such as Cynic philosophers - as an inhuman and shameful act. Only in extreme situations such as war it seems to have been tolerated. In addition, the disposal of human remains like rubbish (e.g. átaphon rhiptesthai; katakremnizein) became a post-mortem insult and a capital punishment against convicted criminals such as traitors and temple-robbers and people categorised as bad and dangerous. Disposal over the boundaries of the community (ekbállein) or into the sea (katapontízein; katapontóein) made persons invisible and placed them outside of the community. Therefore, whenever offenders were punished by being cast into the sea or devoured by animals, it seems reasonable to assume that these modes of disposal were aimed at extinguishing the social memory of wrong-doers. The exhumation of burials, resulting in the careless deposition of their contents, was necessarily a symbolic statement of disgrace. In cases where people were executed and punished 'in the same way as', for example, a traitor, the disposal method was used as a powerful means to express the esteem in which the individual was held either by individuals or by the social and political group in power. This supports once more the social significance of bodies in the manipula-

\section{List of Abbreviations}

POxy. $=$ Greenfell, B. P. and Hunt, A. S. (eds.) 1896 - . Oxyrhynchus Papyri. London: Egypt Exploration Society.

SIG3 = Dittenberger, W. (ed.) 1915-24. Inscriptionum Graecarum, $3^{\text {rd }}$ ed. Leipzig: B. G. Teubner.

SVG $=$ Arnim, H. von 1921-24. Stoicorum Veterum Fragmenta. Leipzig: B. G. Teubner.

tion of social identities and status (cf. Mitteilungen des Deutschen ArchäoloParker 1996, 46).

\section{References} gischen Instituts, Athenische Abteilung

Antanaityte, J. 1998. Interpreting the Meaning of East Baltic Neolithic Symbols. Cambridge Archaeological Journal 8, 55-68.

Bremmer, J. 1983. The Early Greek Concept of a Soul. Princeton, N.J.: Princeton University Press.

Antonaccio, C. M. 1989. Burial and Ancient Society: The Rise of the Greek City-State, By Ian Morris. Cambridge: Cambridge University Press, American Journal of Archaeology 93, 296-7.

Camp, J. McK. 1979. A Drought in the Late Eighth Century BC. Hesperia 48: 397-411.

Cantarella, E. 1991. I Supplizi Capitali in Grecia e a Roma. Milan: Rizzeli.

Axarlis, N. 1998. Plague Victims found: Mass burial in Athens http:// www.archaeology.org/online/news/ kerameikos.html. (Archaeological Institute of America, $15^{\text {th }}$ April 1998)

Baziotopoulou-Valavani, E. and Tsirigoti-Drakotou, J. 2000. Kerameikos-Station, in The City beneath the City. Antiquities from the Metropolitan Railway Excavation. Athens: N.P. Goulandris Foundation, 265-74.

Bergemann, J. 1999. Gräber, Grabbauten, Grabbezirke: Nekropolen und Geschichte zehn Jahre nach "Burial and Ancient Society".

Diehl, E. 1974. Die Hydria. Formgeschichte und Verwendung im Kult des Altertums. Mainz: P. von Zabern Verlag.

D’Onofrio, A. M. 1993. Le Trasformazioni del Costume Funerario Ateniese nella Necropoli Pre-soloniana del Kerameikos, Annali di Archeologia e Storia Antica 15, 143-71.

Douglas, M. 1995/1966. Purity and Danger. An Analysis of the Concept of Pollution and Taboo. London and New York: Routledge. 
Dreimann-Merten, M. 1986. Zur Sozialgeschichte Jacoby, F. 1923-58. Fragmente der griechischen des Kindes im Antiken Griechenland, in Historiker. Berlin: Weidmann.

Martin, J. and Nitschke, A. (eds), Zur Sozialgeschichte der Kindheit (Veröffentlichungen des Instituts für his- Kajanto, J. 1962. On the Problem of 'Names of torische Anthropologie e.V. 4). Freiburg: K. Albert, 267-316. Humility' in Early Christian Epigraphy. Arctos 3: 45-53.

Dusenbery, E. B. 1998. Samothrace. The Necropo- Kerkhecker, A. 1999. Callimachus' Book of Iambi. leis 1. The Necropoleis and Catalogues of Burials (Samothrace. Excavations by the Institute of Fine Arts of New York Univer- Köberle, C. and Rohweder C. 1991-2. Die sity 11; Bollingen Series 60). Princeton, N.J.: Princeton University Press.

Felton, D. 1999. Haunted Greece and Rome. Ghost Stories from Classical Antiquity. Austin: University of Texas Press.

French, V. 1988. Birth Control, Childbirth and Early Childhood, in Grant, M. and Kitzinger, R. (eds.), Civilization of the Ancient Mediterranean. Greece and Rome 3. New York: C. Scribne's Sons, 1355-62.

Garland, R. 1985. The Greek Way of Death. Ithaca: Cornell University Press.

Golden, M. 1981. Demography and the Exposure of Girls in Athens, Phoenix 35, 316-31.

Graf, F. 1978. Die Lokrischen Mädchen. Studi $e$ Materiali di Storia delle Religioni 2, 61-79.

Henderson, J. 1975. The Maculate Muse. Obscene Language in Attic Comedy. New Haven and London: Yale University Press.

Herter, H. 1973. Theseus, in Wissowa, G. and Kroll, W. and Mittelhaus, K. (eds.), Paulys Realencyclopädie der classischen Altertumswissenschaft Suppl. 13. Munich: A. Druckemüller Verlag, 1046-238.

Hope, V. M. 2000. Contempt and Respect: the Treatment of the Corpse in Ancient Rome, in V. M. Hope and E. Marshall (eds.), Death and Disease in the Ancient City: London and New York: Routledge, 104127.

Hubert, J. 1999. Universality and Diversity. A Comparative Look at Rituals of Death and Burial, paper presented at Anthropology and Archaeology in Dialogue. The Issue of Comparison. Seminar held 6-8 November 1999 at the Archaeological Society, Athens. "Dunklen Jahrhunderte": von der Unterwelt aus gesehen. Eine Auseinandersetzung mit Ian Morris, Burial and Ancient Society. The Rise of the Greek City-state (1987), Boreas 14-15, 5-13.

Koehler, C. G. 1986. Handling of Greek transport amphoras, in Empereur, J.-Y. and Garlan, Y. (eds.), Recherches sur les amphoras grecques. Actes du colloque international organisée par le Centre de la Recherche Scientifique, 1'Université de Rennes II et l'Ecole Française d'Athènes. Athènes, 10 12 Septembre 1984 (Bulletin de Correspondance Hellénique, Suppl. 13). Paris: de Boccard, 49-67.

Kunze-Götte, E., Tancke, E. and Vierneisel, K. 1999. Die Nekropole von der Mitte des 6. bis zum Ende des 5. Jahrhunderts. Die Beigaben (Kerameikos 7.2). Munich: Hirmer Verlag.

Kurtz, D. C. and Boardman, J. 1971. Greek Burial Customs (Aspects of Greek and Roman Life). London:, Thames and Hudson.

Kyle, D. G. 1993. Disposal of victims from Roman Arenas, American Journal of Archaeology 97, 306 .

Kyle, D. G. 1998. Spectacles of Death in Ancient Rome. London and New York: Routledge.

Lang, F. 1996. Archaische Siedlungen in Griechenland. Berlin: Akademie Verlag.

Lang, M. L. 1956. Numerical Notation on Greek Vases. Hesperia 25, 1-25.

Lawall, M. L. 2000. Graffii, Wine Selling, and the Reuse of Amphoras in the Athenian Agora, c. 430 to 400 BC. Hesperia 69 , 3-90.

Lidell, T. H. G., Scott, R. and Jones, H. S. (eds.) 1951. A Greek-English Lexicon. $9^{\text {th }}$ ed. Oxford: Clarendon Press. 
Loraux, N. 1987/5. Tragic Ways of Killing a Woman. Cambridge, Mass.: Harvard University Press.

Lüdorf, G. 1998-9. Leitformen der attischen Gebrauchskeramik. Der Bienenkorb. Boreas 21-2, 41-170.

Mahaffy, J. P. 1883. Social Life in Greece. From Homer to Menander, 5th ed. London: MacMillan and Co.

Meiklejohn, C., Brinch-Petersen, E. and Alexandersen, V. 1998. The later Mesolithic Population of Denmark and the Neolithic Transition, in Zvelebil, M., Dennell, R. and Domanska, L. (eds.), Harvesting the Sea. Farming the Forest. Sheffield: Academic Press, 203-213.

Morris, I. 1987. Burial and Ancient Society. The Rise of the Greek City-state (New Studies in Archaeology). New York: Cambridge University Press.

Morris, I. 1989. Circulation, Deposition and the Pritchett, W. K. 1985a. Studies in Ancient Greek Formulation of the Greek Iron Age. Man $24,502-19$

Morris, I. 1992/3. Law, Culture and Funerary Art in Athens, 600 - 300 B.C. Hephaistos 11/12, $35-50$

Morris, I. 1995. Burning the Dead in Archaic Athens: Animals, Men and Heroes, in Verbanck-Pièrard, A. and Viviers, D. (eds.), Culture et Cité. L'avènement d'Athènes à l'époque archaïque. Actes du Colloque international organisé l'Université libre de Bruxelles du 25 au 27 avril 1991 par l'Institut des Hautes Ètudes de Belgique et la Fondation Archéologique de l'ULB. Bruxelles: Fondation Archéologique de 1'Université libre de Bruxelles, 45-74

Morris, I. 1996/2. Death-Ritual and Social Structure in Classical Antiquity (Key Themes in Ancient History). Cambridge: Cambridge University Press.

Morris, I. 1998. Burial and Ancient Society after Ten Years, in Marchegag, S. and Le Dinahet, M.-T. and Salles, J.-F. (eds.), Nécropoles et pouvoir. Idéologies, Pratiques et Interprétations. Actes du Colloque
Théories de la Nécropole Antique, Lyon 21-25 Janvier 1995. Paris: de Boccard, 2136.

Morris, I. 2000. Archaeology as Cultural History. Words and Things in Iron Age Greece. Oxford: Blackwell.

Papachatzi, N. D. 1979. Pausaníou Elládos Periégesis 3. Messeniaká kaì Eliaká. Athens: Ekdoti Athenaion.

Parker, R. 1996/84. Miasma. Pollution and Purification in Early Greek Religion. Oxford: Clarendon Press.

Perdrizet, P. 1921. Copria. Revue des Etudes Anciennes 23, 85-94.

Pomeroy, S. B. 1997. Families in Classical and Hellenistic Greece. Representations and Realities. Oxford: Clarendon Press. Topography 5. Berkeley and Los Angeles: University of California Press.

Pritchett, W. K. 1985b. The Greek State at War 5. Berkeley and Los Angeles: University of California Press.

Rogers, B. B. 1938. Aristophanes 1. Acharnias. The Knights. The Clouds. The Wasps (The Loeb Classical Library). London: Heinemann Ltd.

Romaios, A. K. 1929. He kátharsis tes Delou kaì to Eurema tou Stauropoúllou. Archaiologikón Deltion 12, 181-224.

Roncoroni, P. in press. Bemerkungen zur Deutung von Gräbern in früheisenzeitlichen Siedlungen Latiums als Hausbestattungen, Caeculus.

Shepherd, G. 1995. The Pride of Most Colonials. Burial and Religion in the Sicilian Colonies. Acta Hyperborea 6, 51-82.

Snodgrass, A. 1980. Archaic Greece. The Age of Experiment. London: J. M. Dent.

Sourvinou-Inwood, C. 1995. Reading Greek Death to the End of the Classical Period. Oxford: Clarendon Press. 
Stein-Hölkeskamp, E. 1989. Adelskultur und Polis-

gesellschaft. Studien zum griechischen Vergine, L. 1997. Trash. From Junk to Art. Milano: Adel in archaischer and klassischer Zeit. Stuttgart: F. Steiner.

Themelis, P. G. 1982. Kaíadas. Archaeologiká Weiss, E. 1921. Kinderaussetzung, in Wissowa, G. Análekta ex Athenón 15, 183-201. Electa. and Kroll, W. (eds.), Paulys Realency- 